\title{
Women Mayors in Portugal: A Case Study in Political Representation and Citizenship
}

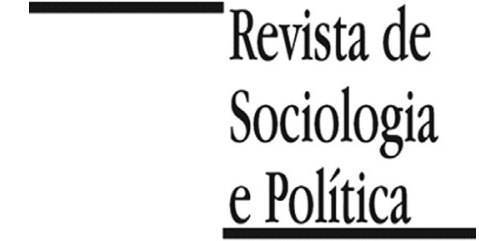

DOI $10.1590 / 1678987318266804$

\section{Maria Antónia de Figueiredo Pires de Almeida iD}

\begin{abstract}
Introduction: The article presents a historical analysis of the participation of women in Portuguese politics and reveals the positive effects of the introduction of the parity law in 2006. In the 2015 national elections, for the first time one third of the elected the Members of the Portuguese Parliament were women. However, in municipalities there is still a long way to go to reach this level of female political representation. Does the political system limit women's access only to elected positions? Thus, important questions remain: why are women still a minority in local politics? What obstacles do they encounter? And what can be done to improve the situation? Materials and Methods: For this investigation, data were collected on the electronic pages of municipalities and political parties, as well as in the press, to monitor the evolution of the presence of women in Portuguese local government, initially as members of the administrative commissions appointed to manage municipal councils from 1974 to the first elections that took place on December 12, 1976 and then as elected representatives from 1976 to the latest 2017 local elections, comparing this level with central government. Results: The study of this group reveals higher educational levels and more specialized jobs among women than among men, particularly in teaching and management. There is also discussion of partisan membership and it is revealed that left-wing parties invest more in women for local government than do right-wing parties. Discussion: Although four decades have passed since the democratic regime was established, the representation of women in politics is still incipient. We present some examples of policy actions that can encourage the presence of women in local government and increase their role as active citizens.
\end{abstract}

KEYWORDS: women; mayors; democracy; parties; Portugal.

Received in November 17, 2017; Accepted in May 1, 2018.

\section{Introduction ${ }^{1}$}

${ }^{1}$ We thank the anonymous reviewers of the Revista de Sociologia e Política for their comments on this article.
$\mathrm{T}$ he Portuguese 25th April 1974 revolution introduced a process of democratization put in practice with the first elections for a Constitutional Parliament on 25th April 1975 and the approval of a Constitution on 2nd April 1976. It was also the beginning of women's broad participation in elections, both as voters and elected representatives, as well as their recognition as equal to men in all aspects of social, economic and political life. The problem is: one would expect, as a general hypothesis, that the democratization process would bring about equal rights and representation for men and women, which has not happened yet. This article presents a historical analysis of women's participation in Portuguese politics until the national elections of 2015, when for the first time one-third of the elected the Members of the Portuguese Parliament were women, due to the enforcement of a parity law. However, in local government, there is still a long way to go to achieve such levels of female political representation.

Some social scientists defend the thesis that women who participate in politics do not crave for power as men do: they instead want to change society for the best (Barros 1999). Others say that the political system still limits women's access and women, themselves, tend to keep away because they feel powerless to change it (Viegas \& Faria 1999). Much more could be added, like the negative image many politicians have in the present times, particularly at the local level, with ties to corruption, which women do not usually want to be associated 
with, or the party system which still regards women as strangers, especially in the majority parties.

Without any doubt, gender-wise Portugal is on the right track, but the questions remain: why are women in local politics still a minority? What obstacles do they face? Moreover, what may be done to change this? There are several hypotheses: improving education levels of the general population, fighting low civic participation and trying to change the existing behaviour differences in national and local party committees.

In order to understand this, we follow the evolution of women in the Portuguese local government, first as proposed members of the earlier administrative committees which ruled municipalities from 1974 until the first local elections which took place on 12th December 1976, and then as elected representatives from 1976 to the latest 2017 local elections, comparing this level with central government. Trying to present some hope for change, we show some examples of political actions that may encourage female presence in local government and increase their role as participative citizens.

A large study of local government in Portugal has already been conducted and published. A database was constructed with information from institutional sources, such as official government journals, municipal and district archives, the national election committee and, for mayors elected after 2009, the press and municipal and government websites. This led to a database with more than 6,000 entries for 3,102 mayors (and deputy mayors, chairmen, and members of administrative committees who were nominated between 1974 and 1976) and 402 civil governors (with their replacements) between 1936 and 2013 in the 18 districts of mainland Portugal and the four island districts that make up the current regional governments of Madeira and the Azores. This database holds a detailed list of names, including information on the individual's age, the dates on which they were appointed and dismissed, the duration of their mandates, their level of education, their profession and social and family background, as well as their prior and subsequent political careers (Almeida 2013; 2014; 2017). For this research new data has been collected from municipalities' and parties' official sites, as well as the press.

Although in Portugal four decades of the democratic regime have gone by, women's representation in Portuguese politics is still low. However, a sociological study of this group reveals higher educational levels and specialised jobs, particularly in teaching and management. If women in representative jobs are indeed more educated than men, could they have more to contribute to the mayor's office? Party membership is also discussed, revealing that left-wing parties invest more in women in local government than right-wing parties do.

\section{Historical framework of women in Portuguese politics}

Briefly analysing the gender question in Portugal, the first woman to ever vote in this country was called Carolina Beatriz Ângelo. She was a medical doctor, a widow and a mother who, in 1911, required the right to vote as a family head. Lacking specific laws regarding gender, the case went to court. She won and exercised her right to vote. The law was altered immediately after, denying this right to women. Later, in 1931, for the first time in Portugal, there was a law allowing women to vote, as long as they were family heads (Decree n. 19694 , 5th May 1931). Nonetheless, this law had significant gender discrimination: men only had to prove they could read and write, whereas women had to show a high school or university diploma. Two years later, the female vote enlarged to emancipated women, and they were allowed to be council members in their municipalities (Decree n. 23 406, 27th December 1933). Also, Law n. 2137, 23rd 
December 1968, no longer distinguished Portuguese citizens by gender. It defined electors to the National Assembly (the Upper Parliament) as "Portuguese citizens, adults or emancipated who may read and write". Nevertheless, considering deficient literacy levels, particularly for women, restrictions for female voters were still very deep within society. Under these circumstances, active female participation in national politics was quite reduced. From 1934 to 1973 there were 21 female Members of Parliament, both in the National Assembly and the Corporative Chamber (Vargas 2000), a 1.3 percentage of a total of 1601 MPs throughout those years (Cruz \& Pinto 2005). As for cabinet members, the first and only woman appointed was Maria Teresa Lobo, Undersecretary of State of Social Assistance in 1971. Regarding Southern European totalitarian regimes, this process is similar to Spain, where women were allowed to vote since 1933 but different from the Italian fascist regime, where women were not allowed to vote. It wasn't until 1948, with the new Italian Constitution, that women were given for the first time the right to vote and be elected.

After the 25th April 1974 revolution, a law was passed on May of the same year which introduced total gender equality (Law n. 621-A/74, 14th May 1974), just as many other laws were issued on the revolutionary period of 1974-1976 to pave the way towards political, social and civic rights gender equality. Such were the cases of free health care, family planning, abortion and, the most recent, medically assisted reproduction for all women, regardless of partner and sexual orientation in 2016 (Zimler 2017), all included in the National Health System. Portugal is part of a small number of the most advanced countries in these matters of law and women's rights.

On 25th April 1975, one year after the revolution, the first democratic and universal elections were held in Portugal. Members of a Constitutional Parliament were elected, whose job was to write down a new democratic Constitution, approved on 2nd April 1976. On 25th April 1976 there were the first general elections for Parliament, and on 27th June 1976, there were the first presidential democratic elections. Since then Portugal has a semi-presidential regime and there have been regular elections. The following parties have elected political representatives for the Portuguese Parliament, for the European Parliament, for municipalities and parishes: PCP, the Portuguese Communist Party, founded clandestinely in 1921; PS, the Socialist Party, founded clandestinely in 1973 (both became legal after the 1974 revolution); PPD/PSD, the Social Democrat Party, founded in 1974; CDS-PP, the Popular Party, centre-right, founded in 1974; UEDS, the Union of the Left for Socialist Democracy, 1978 to 1986; PEV, the Green Party, founded in 1982, generally in coalition with the Communist Party); PRD, the Democratic Renewed Party, 1985 to 2000; BE, the Left Block, founded in 1999, which gathered several left-wing parties outside the Portuguese Communist Party spectrum. In sum, the Socialist Party was the first to win the elections in 1975 and 1976, followed by a centre-right wing coalition of PSD-CDS-PP in 1979. Throughout this entire period these two political forces, the Socialist Party on centre-left and the Social Democrat Party, in centre-right, both single or coalition, have rotated in government.

In 1979, for the first and only time, there was a woman Prime-Minister for five months: Maria de Lourdes Pintasilgo, a chemical engineer who had been a member of the lower chamber of the Portuguese Parliament during the final stage of the Estado Novo regime (1969-1974). She was a Minister of Social Affairs in 1974-1975. After being Prime-Minister, she was appointed UNESCO ambassador, and she was an adviser to President Ramalho Eanes. In 1986 she was elected a member of the European Parliament, in the Socialist Party's lists.

After Pintassilgo, it wasn't until 1985 that a Prime-Minister, Cavaco Silva, invited another woman to be a minister in his cabinet: Leonor Beleza, Health 
Minister. Women's participation in Portuguese governments from 1976 to 1995 was limited to 6 ministers, 33 secretaries of state and 4 undersecretaries of state. This adds up to 44 women, a total of 5.8 per cent of total cabinet members throughout this period. In the Socialist Government, inaugurated on November 2015, on a total of 60 cabinet members, there are 19 women (31.7 per cent): 4 female ministers (Minister of the Presidency and Administrative Modernization, Minister of the Interior, Minister of Justice and Minister of the Sea) and 15 secretaries of state (see Table 1). As usual, the percentage of women is higher in subordinate positions.

The first woman civil governor was appointed in 1980. Until 19943 more were appointed, which, for a total of 114 civil governors appointed from 1974 to 1994, represents 3.5 per cent (Jan 1994).

Regarding Members of Parliament, there were 19 women elected in 1975 (7.7 per cent) to the Constitutional Assembly. The figures in Table 2 demonstrate the slow evolution of women in Portuguese politics. The Communist Party always had the most significant percentage of women elected for Parliament, followed by the Socialist Party (Freire 2001), which practised an internal rule of party quotas since 1988 (Espírito-Santo 2015).

In the 2005 general election, this panorama has changed with a large percentage of women elected MPs on the Left Block and the Socialist Party. Particularly on the Left Block, a party which introduced gender equity in its electoral lists and the circular replacement of MPs throughout the mandate ever since it was created in 1999 state (see Table 2).

This evolution was largely influenced by the introduction of a parity law in 2006, first applied in the 2009 general and local elections (Law n. 3/2006, $21^{\text {st }}$ August 2006, by a Socialist Government), which enforced a 33 per cent minimum for each gender in candidates' lists. It was widely discussed at the time and it is still controversial, particularly regarding the merit criteria (Santos, Amâncio \& Alves 2013), even though it did produce immediate effects in women's election to MP positions. In 2009 a government campaign was launched to divulge this law: it was called "Women make democracy better. Difference produces equality" (CIG 2017). And achieving one third female MPs in the 2015 general elections has definitely contributed to place Portugal in the $8^{\text {th }}$ position of the "Girl's Opportunity Index", above Switzerland ( $\left.9^{\text {th }}\right)$, the United Kingdom $\left(15^{\text {th }}\right)$ and the United States $\left(32^{\text {nd }}\right)$ (Save the Children Fund 2016, p.24). On March 2018 there was a proposal to change this law into a 40 per cent minimum.

The gender composition of assemblies is slowly changing to include more women, and it was demonstrated that issues surrounding concerns with women's interests and with the quality of democracy are strongly related to a desire for a gender equilibrated political environment (EspíritoSanto 2016).

Table 1 - Women Members of the Portuguese Government, 2015

\begin{tabular}{lcccc}
\hline & Male & \% M & Female & \% F \\
\hline Prime Minister & 1 & & & \\
Ministers & 13 & 76.5 & 4 & 23.5 \\
Secretaries of & 27 & 64.3 & 15 & 35.7 \\
State & & & & \\
\hline
\end{tabular}

Source: The author, based on Portugal (2016). 
Table 2 - Women Members of Parliament in Portugal in the Democratic regime

\begin{tabular}{|c|c|c|c|c|c|c|c|c|c|c|c|}
\hline Years & $\begin{array}{l}\text { Total } \\
\text { MPs }\end{array}$ & $\begin{array}{c}\text { Total } \\
\text { Women }\end{array}$ & $\begin{array}{l}\text { Percentage } \\
\text { of women }\end{array}$ & PCP & PEV & BE & UEDS & PS & PRD & PPD/ PSD & CDS-PP \\
\hline 1976 & 263 & 15 & 5,7 & 6 & & & & 6 & & 2 & 1 \\
\hline 1980 & 250 & 17 & 6,8 & 5 & & & 1 & 1 & & 9 & 1 \\
\hline 1985 & 250 & 16 & 6,4 & 7 & & & & 1 & 3 & 5 & 0 \\
\hline 1987 & 250 & 19 & 7,6 & 3 & 1 & & & 4 & 1 & 10 & 0 \\
\hline 1991 & 230 & 20 & 8,7 & 2 & 1 & & & 7 & & 10 & 0 \\
\hline 1995 & 230 & 28 & 12,2 & 2 & 2 & & & 14 & & 7 & 3 \\
\hline 1999 & 230 & 40 & 17,4 & 3 & 2 & 0 & & 23 & & 11 & 1 \\
\hline 2002 & 230 & 45 & 19,6 & 2 & 2 & 0 & & 22 & & 18 & 1 \\
\hline 2005 & 230 & 49 & 21,3 & 2 & 1 & 4 & & 35 & & 6 & 1 \\
\hline 2009 & 230 & 63 & 27,4 & 2 & 1 & 6 & & 28 & & 22 & 4 \\
\hline 2011 & 230 & 61 & 26,5 & 2 & 1 & 4 & & 18 & & 31 & 5 \\
\hline 2015 & 230 & 76 & 33 & 6 & 1 & 6 & & 27 & & 29 & 7 \\
\hline
\end{tabular}

Source: The author, based on Pordata (2015).

\section{Women in Local Government}

At present there are 308 municipalities in Portugal founded, in most cases, in the middle-ages. They are ruled by an elected mayor and a group of councillors. The local electoral process is based on lists of candidates who run for the major political parties or, since the 2001 election, on GCE: groups of citizens, which is to say, independent voters associations (Almeida 2008). The winner list elects the mayor, and the number of councillors for each party is proportional to the electoral results. So the body of councillors is multi-partied, and they all have to work together and run the municipality for four years.

After 25th April 1974, old mayors were dismissed by decree and administrative committees were appointed for each municipality. These commissions were supposed to be composed of independent personalities or groups and political currents which identified themselves with the Movement of Armed Forces and should function until the first democratic local elections took place. In most cases, local citizen comities affiliated to the Communist Party presented the list of the commission members to the Ministry of Interior and were immediately approved. The role of Communist Party local leaders was fundamental to the attraction and mobilisation process of the people who actively participated in the replacement of the mayors and all the presidents of economic and corporative institutions.

There was almost complete discontinuation of the local political elites. Traditional elites were mostly landowners, especially on the southern latifundium region. Nowadays those groups don't even run for local elections. Moreover, economic power is no longer a way of conquering local political leadership. New professions emerged in the group that controls political jobs. Economic elites based on land ownership are entirely and deliberately absent from local politics (Almeida 2013).

There were 464 individuals appointed presidents of the administrative committees from 1974 until the first democratic local elections held 12th December 1976. This was the first time women were appointed to lead municipalities. During the Estado Novo regime, women were allowed to run for municipal councils, and there were some who were elected councillors, but no mayors. In 
1973 there was a woman appointed a vice-president of a municipality. Nonetheless, there were only 9 women appointed presidents of the administrative committees, representing 1.9 per cent. Also, from a total of 2547 members of these commissions, there were 92 women (3.6 per cent).

After over half a century of mayors being appointed by the central government, from 1976 on they were elected by the people, mediated by the political parties. With the regime's transition, there was an almost complete replacement of the local political and economic elites: less than 3 per cent of the old mayors were elected afterwards and only for a very short period.

There has been a real reinforcement of local democracy. After a much-centralised regime, which deprived municipalities of its centuries' old tradition of autonomy, the goal of the new legislators was to create a safety net of several layers of government to protect the citizens from the return of another potentially authoritarian regime (Phillips 1996). All political forces quite readily accepted the decision to decentralise and strengthen local government at the municipal level at the time (Pereira 1991).

However, regarding the gender issue, the local government has still a long way to go. On the first 1976 local elections, only 5 women mayors were elected (1.6 per cent). These figures have been growing, but at a much slower pace than Members of Parliament: on the 2013 local elections only 22 women mayors were elected (7.1 per cent), whereas on Parliament 33 per cent of elected MPs in 2015 were women (Graph 1). In 2017 the number of elected women mayors has grown to 32 , raising the percentage to $10.4,18$ of them with the Socialist Party (56.3 per cent). 75 women were nominated vice-president within the local council (24.4 per cent). In a sum of 2072 elected councillors, 610 were women (29.4 per cent). However, these figures are still far from the required third state (see Table 3 and Graph 1).

In local government, the levels of academic achievement are higher in female than in male politicians, fitting into the Portuguese demographic reality, where, for instance, in 1991 women enrolled in universities represented 55.5 per cent of the undergraduate population. Regarding the total university graduates, women represented 65.7 per cent. Also, on the professional level, women are gaining positions on jobs usually reserved to men, in such fields as law, police and diplomacy (Viegas \& Faria 1999). Teachers and health professionals have the highest percentages of women in its workforce. The same applies to female mayors in Portugal: 70 per cent of the women mayors from 1976 to 2017

Graph 1 - Percentage of women elected Members of Parliament and Mayors

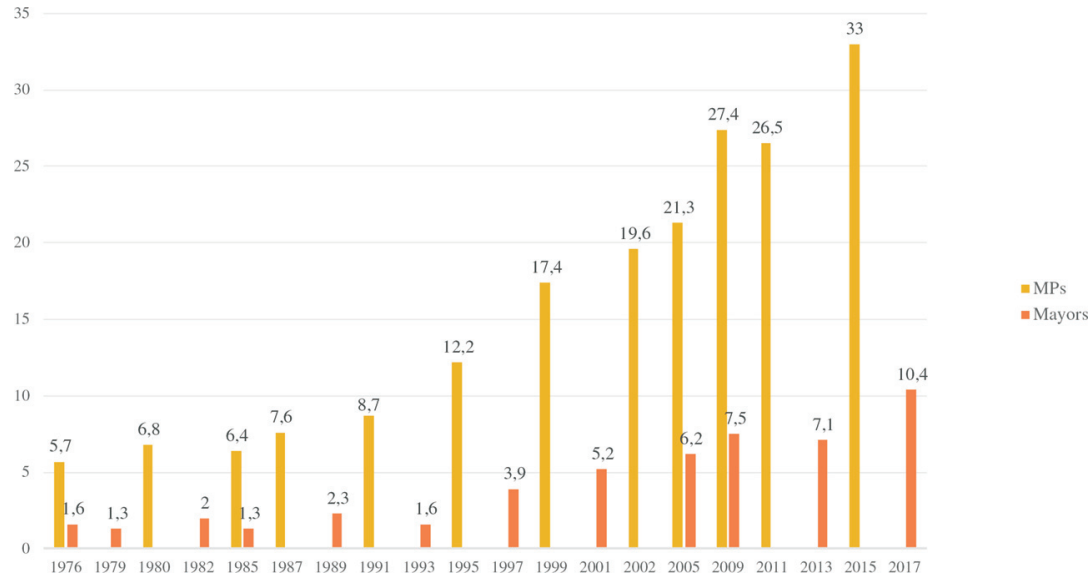

Source: The author, based on CNE (2016) and Almeida (2013; 2014). 
Table 3 - Elected mayors in Portugal, 1976-2017

\begin{tabular}{lccccc}
\hline $\begin{array}{l}\text { Election } \\
\text { dates }\end{array}$ & $\begin{array}{c}\text { Elected } \\
\text { women }\end{array}$ & $\%$ & Elected men & $\%$ & Total \\
\hline 1976 & 5 & 1,6 & 299 & 98,4 & 304 \\
1979 & 4 & 1,3 & 301 & 98,7 & 305 \\
1982 & 6 & 2 & 299 & 98 & 305 \\
1985 & 4 & 1,3 & 301 & 98,7 & 305 \\
1989 & 7 & 2,3 & 298 & 97,7 & 305 \\
1993 & 5 & 1,6 & 300 & 98,4 & 305 \\
1997 & 12 & 3,9 & 293 & 96,1 & 305 \\
2001 & 16 & 5,2 & 292 & 94,8 & 308 \\
2005 & 19 & 6,2 & 289 & 93,8 & 308 \\
2009 & 23 & 7,5 & 285 & 92,5 & 308 \\
2013 & 22 & 7,1 & 286 & 92,9 & 308 \\
2017 & 32 & 10,4 & 276 & 89,6 & 308 \\
Average & $\mathbf{1 2 , 9}$ & $\mathbf{4 , 2}$ & $\mathbf{2 9 3 , 3}$ & $\mathbf{9 5 , 8}$ & $\mathbf{1 0 0}$ \\
\hline
\end{tabular}

Source: The author, based on CNE (2016) and Almeida (2013; 2014).

was in intellectual and scientific professions, which imply a college education. Teachers (at all levels, from grade school to university) were a clear majority (27.6 per cent), and they are members of this group, but they were placed in a separate category in Table 4 and Graph 2 to highlight how strong this professional category is. Regarding the total of mayors elected in this period, intellectual and scientific professions occupy a 46.2 percentage, with teachers at 20.5 per cent. Therefore, there are more women mayors with intellectual and scientific professions, particularly teachers (Almeida 2017a).

Women are also better educated: 58 per cent of female mayors from 1976 on had a college education whereas men only had it in 43 per cent of the cases. As Members of Parliament, women mayors in Portugal were elected mostly with left-wing parties. As we may see on Graph 3, 65 per cent of women mayors have been elected by left-wing parties since 1976 (the Socialist Party, the Communist Party and the Left Block). Moreover, in 2017 the Socialist Party elected 18

Table 4 - Women mayors, professions and political parties, 1976-2017

\begin{tabular}{|c|c|c|c|c|c|c|}
\hline Professional group / Political party & BE & CDS / PPM & PCP (CDU) & PS & PSD & GCE \\
\hline Bank clerks & & & 2 & & 1 & \\
\hline No job & & 1 & & & & \\
\hline Managers & & & & 1 & 1 & \\
\hline Intellectual and scientific professions & & & 8 & 13 & 7 & 1 \\
\hline Public servants & & & 1 & 2 & 5 & \\
\hline Clerks and salespeople & 1 & & 1 & & & \\
\hline Teachers & & & 4 & 12 & 7 & 1 \\
\hline CEOs (public or private) & & & & 2 & 3 & \\
\hline Technicians & & & 2 & 3 & & \\
\hline Total & 1 & 1 & 18 & 25 & 21 & 2 \\
\hline
\end{tabular}

Source: Almeida $(2013 ; 2014)$. 
Graph 2 - Number of women mayors by professional groups, 1976-2017

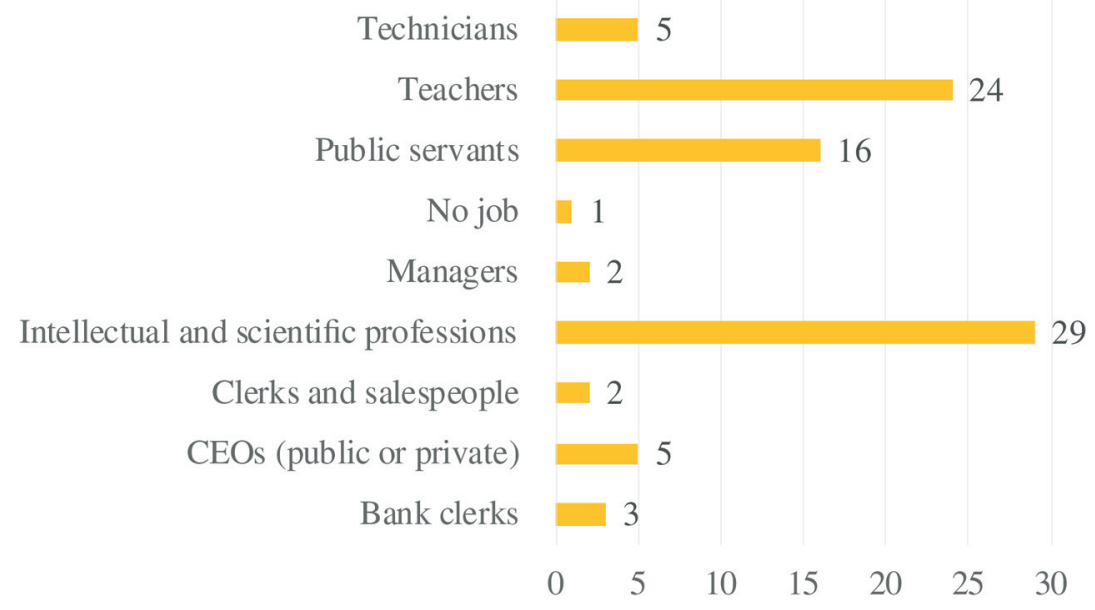

Source: Almeida $(2013 ; 2014)$.

Graph 3 - Number of women mayors by political parties, 1976-2017

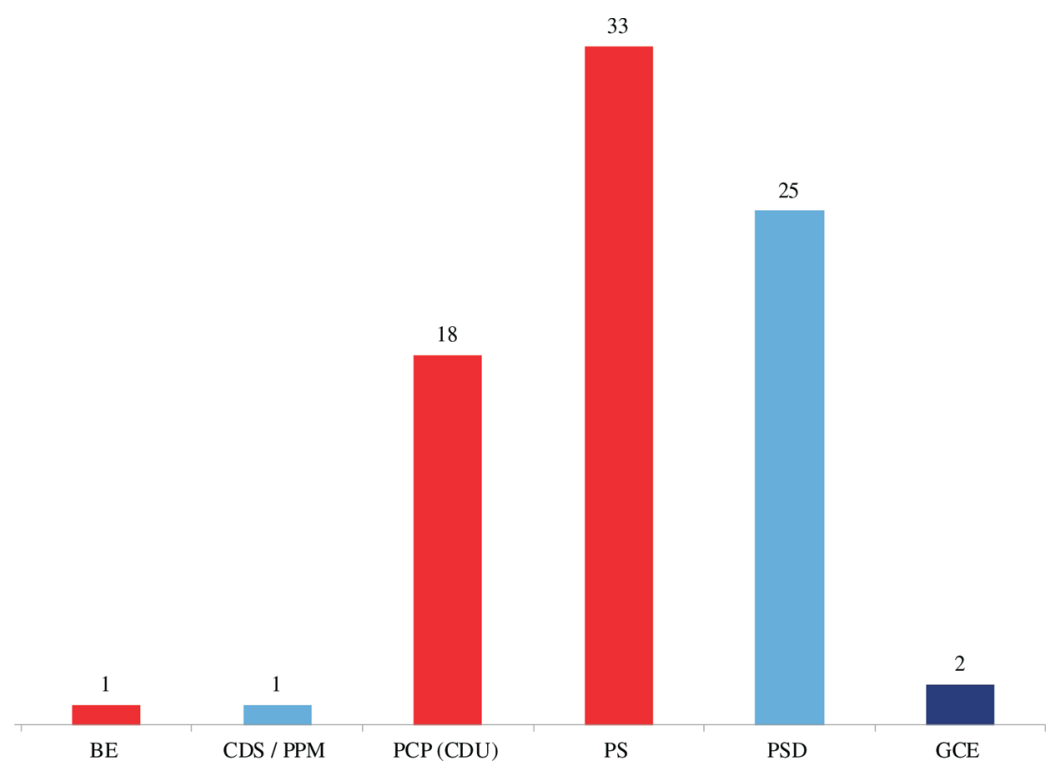

Source: Almeida $(2013 ; 2014)$.

women mayors, and the Communist Party elected 4, which gives left-wing parties a sum of 69 per cent of the municipalities led by women. Therefore, we can apply to Portugal the rule that says that in present day's countries women's values tend more towards the left (Inglehart \& Norris 2003). Also, parties on the left wing spectrum invest more in female representatives than on the right wing, as may be observed, for instance, in Australia (Beauregard 2017).

Regarding the 22 women mayors elected in 2013, on district capitals or municipalities with over 100.000 residents there are at present only 4 female mayors: Amadora, Setúbal, Portalegre and Odivelas. All the main cities have male mayors. Fourteen of the female mayors in duty (63.6 per cent) were previously elected local councillors, 8 of which (36.4 per cent) with the job of vice-president, meaning they were second or third on their parties' lists for some years before they became number one. However, this is also a regular path for men: in a 
total of 308 mayors elected, 63.6 per cent had been local councillors before, of which 33.4 per cent vice-presidents.

In 2015 two more women became mayors in Portugal: they were vice-presidents who have taken the role upon the resignation of the earlier mayors. This fact says a lot about the enforcement of the parity law in local government in Portugal: women are placed on lists, abiding by the law, but not in mayor eligible positions. In 2013 there were 2086 local councillors elected (including mayors), of which 547 women ( 26 per cent), and 55 female vice-presidents (18 per cent). Regarding the 3092 parishes, there were 339 women elected in 2013 (10.96 per cent). Moreover, municipalities with less than 7.500 voters are not forced to comply at all with the parity law.

Of the 8 female mayors who had previously been vice-presidents of the same municipalities, plus 2 who were appointed mayors at mid-mandate, some life stories are interesting to follow: Cristina Mota, from Lagoa, Azores Islands, with a degree in Political Science, was a municipal civil servant, chief of staff of the previous mayor's office, before she was vice-president. Maria Teresa Cardoso, from Anadia, was the vice-president with the PSD; since she was not appointed first on that party's list, she decided to run on an independent list, and she won. Sílvia Pinto and Hortênsia Menino, from Arraiolos and Montemor-o-Novo, both in Southern municipalities, where the Communist Party traditionally wins since 1976, both high school teachers with a career in the Communist Party. Isilda Gomes, from Portimão, a schoolteacher and a local councillor since 2000, was also district governor (2007-2009) and Member of Parliament (2009). All of them had long political paths until becoming mayors.

In 2017, of the 32 elected women mayors, 20 were re-elected, 10 were newly elected, and two of them were vice-presidents who had replaced mayors in mid-term. All of the new women mayors are college educated, with professional paths as intellectuals, specialists and teachers.

Without a doubt, the parity law is easily enforced in general elections for the Portuguese Parliament, as well as in elections for the European Parliament. The evolution is clear, observed in Graph 1. It was evident that the parity law is mostly applied where it is compulsory. Since this law does not enforce the first position on local lists, women are mostly placed in third positions.

There are some explanatory factors for these differences in government levels. First, there may be more potential female candidates in higher level elections, as there seems to be a shortage of supply in lower levels of government; second, there is a concern for the image of Portugal in a European institution, since gender balance favours the international image of a country ${ }^{2}$ as well there is more visibility of the lists and public awareness than in local elections; and third the weight of public opinion, which is not that important in local government, particularly in small municipalities. The main problem in local government is the electoral body which selects candidates. Those are the gatekeepers, usually a man's only club. Alternatively, as Folke and Rickne describe, there is a "glass ceiling" which "implies discrimination in promotions within the political organisation" and "the discriminatory promotions increase in severity at the top levels of power" (Folke \& Rickne 2016).

In the Portuguese local elections, women don't enter the political game until after the lists are ready and there is a lack of supervision mechanisms, as well as weak women's sections inside most parties. At the national level, there is more diversity in those electoral bodies (Espírito-Santo 2015; Espírito-Santo \& Santos 2017). Recruitment is the main issue also in Brazil, where, despite a quota law since 1995, there are no sanctions for not applying it and women mayors are only 12 per cent in 2012 (Meireles \& Andrade 2017). "Machismo" 
and paternalism are still prevalent in this South American country, as in Portugal (Santos, Roux \& Amâncio 2016; Teixeira 2017). Therefore, the process for candidate selection depends mostly on party organisations which reflect this biased view of society (Costa, Bolognesi \& Codato 2013; see also Krook \& Zetterberg 2015).

Some social psychological explanations may also be applied to local level politics, where persists high levels of masculinisation: meritocratic individualism, a widely used argument for men and against women, is one of "those apparently invisible barriers that continue to constrain women's access to certain professions and occupations, as well as making their career progress more difficult and preventing them from reaching the powerful and decision-making positions" (Santos \& Amâncio 2016). On the other hand, there may be self-restraint for women to apply for representative jobs because of recurring sexist behaviours, to avoid exposition. Marisa Matias, a Portuguese Member of the European Parliament and a Presidential candidate who won the third place on the 2016 election, has complained of dreadful sexist insults on her Facebook page (6th June 2017).

Regarding independent voters' associations (GCE), there were 13 independent mayors elected in 2013 (4.2 per cent of municipalities). Only 2 of them were women (Almeida 2016). In the 2017 local elections 17 mayors were elected in independent groups ( 5.5 per cent), three of them women. Considering the constraints local political parties put on women candidates, women should consider moving forward and away from traditional party structures and run as independent citizen groups' leaders. As Adelaide Teixeira, the independent mayor of Portalegre said: "In independent citizen groups we have a kind of freedom that doesn't exist in the parties". (A. Teixeira 2017)

\section{Some hope for the future of female representation in Portuguese politics}

Considering the "politics of presence" thesis that women's interests are better represented by women themselves (Phillips 1995), equality concerning political representation is a requirement and should be a goal to achieve in a near future, not only in the Portuguese local government, but in every aspect of political, social, economic and family life. Unfortunately, women have been known to vote against specific women's issues. In such cases class and party affiliation mostly, but also religion and cultural background, prevail over gender interests. This fact was observed in the Portuguese Parliament by the end of the rightwing coalition government term (Social Democrat Party and Popular Party) on July 2015. A group of women, led by a former social democrat MP, introduced and was able to approve a law which reversed a few of the abortion rights conquered in the 2007 referendum (the same law was reversed right after the Socialist Party's Government was sworn on November of the same year). It was also observed on the 2016 election for the President of the United States of America.

In most established democracies and particularly in Portugal there is a problem of low election turnout, which the current Prime Minister António Costa described as "low turnout disbeliefs" (Freire 2017). After huge turnouts at the beginning of the democratic regime ( 91.7 per cent in 1975 and 83.5 in the 1976 general elections), in the 2013 local elections only 52.6 per cent of voters used their right to vote. Moreover, in the 2015 general elections turnout was 56.9 per cent. Without the participation of voters in the electoral process, democracy may not fulfil its purpose (Freire 2015). Reduced civic and voting participation contribute to a democratic deficit. There is a cycle of disinterest and disenchantment with democracy going on. Probably because citizens don't care: "The argument for citizens to become more intensely engaged in a deeper politics of the 
public realm comes against one telling point: citizens (and the evidence is overwhelming) do not want it [...] Most substantial politics is done by a mixed, but small, cadre of elected politicians, unaccountable officials, specialist lobbyists, narrowly focused experts and professionalised protesters. [...] The average citizen is alienated from politics and far from convinced of its value" (Stoker 2006). In Portugal this is an issue: according to the European Social Survey data for 2012, this country is placed last in citizens' interest in politics (Belchior 2015).

Alternatively, according to political scientist and university professor António Costa Pinto, this political alienation is the Portuguese choice versus the protest vote which is currently in other European countries and gives rise to populism and social movements (Botello 2017).

In Portugal, there may be observed low levels of political engagement and participation, particularly among the youth (Magalhães 2005). Between 2002 and 2009, Portugal was in the lowest level of satisfaction in Europe and going down since 1990 (Norris 2011). According to Baumgarten, there is a deep crisis of the representative democracy in Portugal because of the loss of confidence in politicians. All over Europe, there are low turnouts and citizens are less engaged in traditional institutions, such as parties, unions and the church. The financial crisis made this disengagement worse. There is a democratic deficit on a global scale. Citizens criticise the lack of autonomy of national, regional and local governments and the growing impact of non-elected actors in political decisions (Baumgarten 2015).

However, an extreme crisis may trigger "mobilisation as a reaction to exceptional and perhaps unpredicted contemporary events" (Cairns \& Allaste 2016b). Since 2011, with a massive debt to deal with, the right-wing coalition government went beyond troika induced austerity measures and largely surpassed European impositions. The goal was to concentrate power in their hands, and the debt was a strong argument presented to counter the opponents of their proposed reforms (Moury \& Standring 2017). Facing such personal and social hardships, rising unemployment, precarious jobs, growing neoliberal economy and the loss of hard-conquered social rights, the Portuguese people did react and initiated the most significant social protest in the history of the Portuguese democracy (Seixas et al., 2015). On 15th September 2012, over one million took the streets of dozens of Portuguese towns and some of the traditional political actors, such as unions and left-wing parties, managed to attract the support of new groups (Accornero \& Pinto 2014).

Such demonstrations have also been happening in the USA ever since president Trump took office on January 2017. Mobilisation against specific policies has been a part of the democratic process that may produce significant results.

In Portugal, the younger generations have been disengaged from politics for some reasons. Mostly because they lack confidence in formal politics and politicians. They are also, in most cases, not part of the conventional workforce (youth unemployment is huge in Portugal: 25 per cent in 2014), with precarious jobs and not belonging to any traditional political association, such as parties or unions. In general, the youth prefer "less conventional ways of engaging with the political sphere (they will) focus less on voting in formal elections and rather on more informal and individualised forms of political participation and civic engagement. [...] The repertoires of political engagement have hence become more diverse and less absolute: from consumer politics to community campaigns and international networks; from the ballot box to the street, to the internet; from political parties to social movements and issue groups, to social networks [...] 'sub-politics' and 'life politics' as a means of defining this new reality. [...] these terms represent what takes place in fields outside traditional po- 
litical institutions and corporate systems, encompassing professional groups, issue-specific initiatives, social movements and private individuals. [...] subpolitics presents a viable means of explaining how individuals live out their particular political causes and commitments 'underneath' the surface of formal politics, albeit with strong public and activist element to this definition" (Cairns \& Allaste 2016a).

Pippa Norris differentiates between citizen-oriented actions (mainly about elections and political parties) and cause-oriented repertoires (about specific issues and policy concerns), which "have broadened towards engaging in 'lifestyle' politics, where the dividing line between the 'social' and 'political' is blurred" (Norris 2003).

With all due respect for whatever new forms of political or civic engagement, at the end of the day voting is the way people's representatives are elected and apply policies. After the elections, there may be no regrets, as was observed in the Brexit referendum or the election of President Trump. Voters need to vote in conscience and accept the consequences of the democratic process. Moreover, they have to turn out for elections.

In Portugal, turnout being a primary issue, some incentives need to be put in place to educate young people to vote and be a part of the democratic process. The incentive to more direct citizen participation in debate and decision making is positive to citizens and democracy. Some experiences of political participation may work as a school for democracy (Baumgarten 2015).

Therefore, there needs to be a strong education for citizenship which needs to involve schools. Catarina Marcelino, the former Secretary of State for Citizenship and Equality of the Socialist Government, had proposed in 2016 to work towards citizenship in schools regarding issues such as domestic violence and civic skills (Portugal 2016). She had asked for the help of municipalities in this project. Schools already contribute to youth education regarding political issues by promoting elections for students' representatives. There is also the Parliament of the Youth, a special program of the Portuguese Parliament approved in 2006, aimed at school children from 10 to 18 years old, which encourages students from the 5 th to the 12 th grade to learn the political and legislative process and to participate in political debates first in their schools and finally in the House of Parliament itself. This program focuses on education for citizenship and political participation, as well as teaching how the Parliament functions and the rules of political debate. It promotes sessions in the Parliament for schoolchildren who win school elections promoted within this program (Parlamento dos Jovens 2017). This is a major step in political practice, and sometimes also ground for party recruitment.

One Portuguese municipality has applied the principle of stimulating youth civic participation not only as voters but also as political representatives (Meadowcroft 2001). In Santa Maria da Feira, Oporto district, in the North of Portugal, the municipality has already twice promoted a "Young councillor" project, inspired by Lewisham, London's "Young Mayor" model. The goal was to provide an experience of municipality management to young people. In sum, several high school candidates campaigned for their electoral programs. There were propaganda and school debates. As a result, one 17-year-old girl was elected in 2015 and another 15-year-old girl in 2016. Both received a one-year mandate, a 10,000-euro budget and an 18-member team to manage. According to the mayor of Santa Maria da Feira, Emídio Sousa, this policy was quite successful: "Its major accomplishment is to get young people to think about politics where they live, in their homeland, their neighbourhood [...] who knows, maybe future election turnouts shall grow" (S.D. Oliveira apud Almeida 2016). 
Not only turnout may grow, but also female representation, particularly at the local level. There is a strong probability that experiences such as these shall transform local societies and preferably local party representatives, whose party committees should start paying attention to the most skilled members of their municipalities. Candidates' profile has to change to insert women into suitable places in electoral lists.

\section{Conclusions}

In the last 40 years, Portugal has been through a considerable evolution, from its early revolutionary moments until democratic stability was achieved. Portuguese society accompanied the changing times. Its elites, both political and economic, lead the way for essential transformations. Moreover, they can be seen as a mirror of those same transformations, for their social characteristics reflect the people who vote for them. Presently, with globalisation, extreme debt and austerity measures imposed by the European Union, Portugal faces serious challenges, for which it should be prepared. Portugal's political elites have the skills to overcome these new times: they have the education and the political and professional experience. However, as before the revolution, regarding the gender issue, only the fittest and best prepared (both academically, professionally and insertion into the party system) can achieve the political spotlight. Also, the vast majority of Portuguese women are indeed prepared and fit.

The democratic transition has brought about a sexual revolution in Portugal and, at least in legislation, total gender equality. In local government, there are women mayors, where there weren't any. Also, both the parliament and government have increasing numbers of women. There hasn't yet been a presidential election which gave a woman a victory, although there have been a few candidates. Regarding the workplace, there is gender equality in theory. There are even some professions in which women are prevalent, even though women in top management jobs are still a minority: "in practice, the increase in women's education and their increasing presence in the job market have not been reflected in the positions they occupy, particularly in entities holding economic and political power. Women remain in inferior positions when compared with men and are sent to professions and markedly feminine specialist fields, generally less valued and with lower salaries" (Santos \& Amâncio 2016). To deal with this situation, on February 2017 there was a proposal for a law to force public, and stock market indexed companies to achieve one third female top managers by 2020 , as well as a minimum of forty per cent women in civil service jobs and public universities. It was approved in Parliament on the 23rd June 2017 and published as Law number 62/2017 on the 1st August 2017. Also, on May 2017 a new rule was added to the Public Contracts Code: people and firms convicted of breaking equality and non-discrimination rules are to be excluded from public contracts (S.J. Almeida 2017).

Regardless of the notorious evolution women went through in the Portuguese democratic regime, there is still a long way to go into gender equity in Portugal. Particularly at the local level, party structures in central axis parties are still a significant barrier to women's access to the mayor job. Regardless of this structural condition, many local party leaders and representatives have not yet realised that women may have something to contribute to the political environment. In the 2017 local elections, 21 municipalities have still managed to elect councils without a single woman. This situation is in the hands of local leaders, gatekeepers, who, even with a parity law, don't want to enforce it and keep women in non-eligible places in the candidates' lists. Even when women are, as observed above, more qualified and better educated. Since party struc- 
tures still place obstacles, independent citizen groups may be a way for women to move up the local government ladder.

Voters also need to participate in elections and fight low turnouts. Portuguese society needs to realise that public policies are no luxury, they are an investment, and women may contribute effectively. Essential priorities: fighting gender, cultural, economic, territorial inequalities, among others. Also, policies for education and culture are critical investments for better and more effective citizenship.

Maria Antónia de Figueiredo Pires de Almeida (mafpa@iscte-iul.pt) is a PhD in Modern and Contemporary History by the ISCTE, University Institute of Lisbon (Portugal), and she is a researcher and guest assistant professor at the same Institution. She leads a project on 'Local government in Portugal: political and social responsibility over the sustainable development of unequal territories'. Institutional Affiliation: Centro de Investigação e Estudos em Sociologia, IUL, Lisboa, Portugal.

\section{References}

Accornero, G. \& Pinto, P., 2014. 'Mild Mannered'? Protest and Mobilisation in Portugal under Austerity, 2010-2013. West European Politics, 38(3), pp.491-515. DOI: 10.1080/01402382.2014.937587

Almeida, M., 2008. Party politics in Portugal: municipalities and central government. European Societies, 10(3), pp.357-378.

Almeida, M 2013. O Poder Local do Estado Novo à Democracia: Presidentes de Câmara e Governadores Civis, 1936-2012. Lisbon.

Almeida, M 2014. Dicionário biográfico do poder local em Portugal, 1936-2013. Lisbon.

Almeida, M 2016. Grupos de cidadãos nas autarquias portuguesas: contributo para a prática da cidadania e para a qualidade da democracia? Lisbon.

Almeida, M. 2017. The Revolution in Local Government: Mayors in Portugal before and after 1974. Continuity and Change, 32(2), pp.253-282. DOI: 10.1017/s0268416017000170

Barros, J., 1999. As mulheres e a participação política. In J. Viegas \& S. Faria, eds. As mulheres na política. Lisboa: INCM.

Baumgarten, B., 2015. O futuro dos movimentos sociais na representação sociopolítica. In A. Freire, ed. O Futuro da Representação Política Democrática. Lisboa: Vega.

Beauregard, K., 2017. Support for Gender Quotas and the Role Model Effect in Australia. In European Conference on Politics and Gender. Lausanne.

Belchior, A., 2015. Confiança nas Instituições Políticas. Lisboa: Fundação Francisco Manuel dos Santos.

Bush, S., 2011. International Politics and the Spread of Quotas for Women in Legislatures. International Organization, 65(1), pp.103-137. DOI: 10.1017/s0020818310000287

Cairns, D. \& Allaste, A., 2016a. Youth Political Participation in a Transition Society. Studies of Transition States and Societies, 8(2), pp.1-9.

Bush, S. 2016b. Contextualising Participation in a Transition Society. Studies of Transition States and Societies, 8(2), pp.101-108.

Costa, L.; Bolognesi, B. \& Codato, A., 2013. Variáveis sobre o recrutamento político e a questão de gênero no Parlamento brasileiro. In E. Salgado \& I. Dantas, eds. Partidos políticos e seu regime jurídico: o desenho constitucional dos partidos políticos. Curitiba: Juruá.

Cruz, M. \& Pinto, A., eds. 2005. Dicionário Biográfico Parlamentar. 3 V. Lisboa: Instituto de Ciências Sociais e Assembleia da República.

Espírito-Santo, A., 2015. A Long Way to a Still-Imperfect Parity. EUI Working Papers, LAW 2015/23. Florence: EUI.

Espírito-Santo, A. 2016. Citizens' Attitudes towards Descriptive Representation: The case of women in Portugal. European Journal of Women's Studies, 23(1), pp.43-59. DOI: 10.1177/1350506814568036

Espírito-Santo, A. \& Santos, M., 2017. The Implementation of Gender Quotas across Different Levels of Government: The Case of Portugal. In European Conference on Politics and Gender. Lausanne.

Folke, O. \& Rickne, J., 2016. The Glass Ceiling in Politics: Formalization and Empirical Tests. Comparative Political Studies, 49(5), pp.567-599. DOI: 10.2139/ssrn.2479239

França, P., 1994. Governos Civis. Mais de um século de história. Lisboa: Secretaria-Geral do Ministério da Administração Interna.

Freire, A., ed., 2001. Recrutamento Parlamentar: os Deputados Portugueses da Constituinte à VIII Legislatura. Lisboa: STAPE/MAI.

Freire, A., 2015. O Futuro da Representação Política Democrática. Lisboa: Veja.

Freire, A., 2017. Para lá «Geringonça». O governo de esquerdas em Portugal e na Europa. Lisboa: Edições Contraponto.

Inglehart, R. \& Norris, P., 2003. Rising Tide. Gender Equality and Cultural Change around the World. Cambridge, UK: Cambridge University Press.

Krook, M. \& Zetterberg, P., eds. 2015. Gender Quotas and Women's Representation: New Directions in Research. New York: Routledge. 
Magalhães, P., 2005. Disaffected Democrats: Political Culture and Political Action in Portugal. West European Politics, 28(5), pp.973-991. DOI: 10.1080/01402380500310626

Meadowcroft, J., 2001. Political Recruitment and Local Representation: The Case of Liberal Democrat Councillors. Local Government Studies, 27(1), pp.19-36. DOI: 10.1080/714004092

Meireles, F. \& Andrade, L., 2017. Magnitude eleitoral e representação de mulheres nos municípios brasileiros. Revista de Sociologia e Politica, 25(63), pp.79-101, http://dx.doi.org/10.1590/1678-987317256304.

Moury, C. \& Standring, A., 2017. 'Going beyond the Troika': Power and discourse in Portuguese austerity politics. European Journal of Political Research, 56(3), pp.660-679. DOI: 10.1111/1475-6765.12190

Norris, P., 2003. Young People \& Political Activism: From the Politics of Loyalties to the Politics of Choice? Cambridge, MA: Harvard University Press.

Norris, P. 2011. Democratic Deficit. Critical Citizens Revisited. Cambridge, UK: Cambridge University Press.

Norris, P. \& Krook, M., 2014. Women in Elective Office Worldwide: Barriers and Opportunities. In S. Thomas \& C. Wilcox, eds. Women and Elective Office: Past, Present, and Future. $3^{\text {rd }}$ Ed. Oxford: Oxford University Press.

Pereira, A., 1991. The System of Local Government in Portugal. In R. Batley \& G. Stoker, eds. Local Government in Europe. Trends and Development. London: Palgrave Macmillan.

Phillips, A., 1995. The Politics of Presence. Oxford: Clarendon Press.

Norris, P. 1996. Why does Local Democracy Matter? In L. Pratchett \& D. Wilson, eds. Local Democracy and Local Government. Houndmills: Palgrave Macmillan.

Santos, M.; Amâncio, L. \& Alves, H., 2013. Gender and Politics: The relevance of gender on judgements about the merit of candidates and the fairness of quotas. Portuguese Journal of Social Science, 12(2), pp.133-149. DOI: 10.1386/pjss.12.2.133_1

Santos, M. \& Amâncio, L., 2016. Gender Inequalities in Highly Qualified Professions: A Social Psychological Analysis. Journal of Social and Political Psychology, 4(1), pp.427-443. DOI: 10.5964/jspp.v4i1.487

Santos, M.; Roux, P. \& Amâncio, L., 2016. Expériences et stratégies de femmes investies dans un 'monde d'hommes'. Le cas de la politique locale portugaise. Sociologia Problemas e Práticas, 82, pp.69-87. DOI: 10.7458/spp2016826945

Seixas, J.; Tulumello, S.; Corvelo, S. \& Drago, A., 2015. Dinâmicas sociogeográficas e políticas na Área Metropolitana de Lisboa em tempos de crise e de austeridade. Cadernos Metrópole, 17(34), pp.371-399. DOI: 10.1590/22369996.2015-3404

Stoker, G., 2006. Why Politics Matters. Making Democracy Work. Houndmills: Palgrave Macmillan.

Teixeira, A., 2017. Desigualdades de género nos cargos políticos em Portugal: do poder central ao poder local. PhD Thesis. Lisboa: Universidade Nova de Lisboa.

Vargas, A., 2000. Mulheres na Assembleia Nacional (1933-1974). Eleições, 6, pp.43-67.

Viegas, J. \& Faria, S., 1999. As mulheres na política. Lisbon: INCM.

\section{Newspaper Sources}

Almeida, S.J., 2017. Empresas condenadas por violação das regras de igualdade ficam excluídas de concursos públicos. Público, $19^{\text {th }}$ May. Available in https://www.publico.pt/2017/05/19/politica/noticia/discriminacao-exclui-deconcursos-publicos-1772805. Accessed Dec. 22 2018.

Botelho, L., 2017. Sistema português absorve os populismos à custa da abstenção. Público, 11 ${ }^{\text {th }}$ April. Available in https://www.publico.pt/2017/04/11/politica/noticia/sistema-portugues-absorve-os-populismos-a-custa-da-abstencao-17 68351. Accessed Dec. 22 2018.

Teixeira, A., 2017 Os movimentos de cidadãos assustam os partidos, Jornal I, 19 th $^{\text {June } 2017 .}$ Available in https://ionline.sapo.pt/568483. Accessed Dec. $22^{\text {th }}, 2018$.

Zimler, R., 2017. Portugal's Secret Revolution, Tikkun, Jan. 24 $4^{\text {th }}$. Available in http://www.tikkun.org/nextgen/portugals-secret-revolution. Accessed Dec. $22^{\text {th }}, 2018$.

\section{Other sources}

CNE. Comissão Nacional de Eleições, 2016. Reuniões da CNE. Available at http://www.cne.pt. Accessed Dec. $22^{\text {th }}, 2018$. CIG, 2017. Comissão para a Cidadania e Igualdade de Género. Available in https://www.cig.gov.pt. Accessed Dec. $22^{\text {th }}, 2018$. Parlamento dos Jovens, 2017. Website. Available at http://www.jovens.parlamento.pt. Accessed Dec. $22^{\text {th }}, 2018$.

Portada, 2015. Mandatos nas eleições para a Assembleia da República: deputados do sexo feminino por partido político. Available in https://www.pordata.pt/MicroPage.aspx?DatabaseName=Portugal\&MicroName=Mandatos+nas+eleições+para+a+Assembleia+da+República+deputados+do+sexo+feminino+por+p artido+pol\%C3\%ADtico\&MicroURL=2260\&. Accessed Dec. 22 ${ }^{\text {th }}, 2018$.

Portugal, 2016. Catarina Marcelino anuncia medidas para combater violência doméstica no terreno. República Portuguesa, Jan. $\quad 9^{\text {th }} \quad 2016 . \quad$ Available $\quad$ in $\quad$ https://www.portugal.gov.pt/pt/gc21/comunicacao/noticia?i=20160109-seci-violencia-domestica. Accessed Dec. 22 $2^{\text {th }}, 2018$.

Save the Children Fund, 2016. Every Last Girl. Free to live, free to learn, free from harm. London: Save the Children. Available in https://www.savethechildren.org.uk/content/dam/global/reports/advocacy/every-last-girl.pdf. Accessed Dec. 22 2018. 


\section{As prefeitas em Portugal: um estudo de caso sobre a representação política feminina e a cidadania}

RESUMO Introdução: O artigo apresenta uma análise histórica da participação das mulheres na política portuguesa e revela os efeitos positivos da introdução, em 2006, da lei da paridade. Nas eleições legislativas de 2015 as mulheres constituíram pela primeira vez um terço do total dos deputados eleitos. Contudo, nas autarquias ainda há um longo caminho a percorrer para alcançar esse nível de representação política feminino. Será que o sistema político limita o acesso das mulheres apenas aos cargos eletivos? Assim, persistem questões importantes: por que as mulheres ainda são minoria na política local? Com que obstáculos se deparam? E o que pode ser feito para melhorar a situação? Materiais e Métodos: Para esta investigação foram recolhidos dados nas páginas eletrônicas dos municípios e dos partidos políticos, assim como na imprensa, para acompanhar a evolução da presença das mulheres nas autarquias portuguesas, no início como membros das comissões administrativas nomeadas para gerir as Câmaras municipais desde 1974 até às primeiras eleições que se realizaram em 12 de dezembro de 1976, e depois como presidentes de Câmara e vereadoras eleitas desde 1976 até às mais recentes eleições de 2017, comparando este nível com o governo central. Resultados: O estudo deste grupo revela níveis educacionais mais elevados e mais empregos especializados entre as mulheres do que entre os homens, particularmente em ensino e gestão. Discute-se também a filiação partidária e revela-se que os partidos de esquerda investem mais nas mulheres para o poder local do que os partidos de direita. Discussão: Apesar de já terem passado quatro décadas desde que o regime democrático foi estabelecido, a representação das mulheres na política ainda está muito incipiente. Apresentamos alguns exemplos de ações políticas que podem encorajar a presença de mulheres no poder local e aumentar o seu papel como cidadãs ativas.

PALAVRAS-CHAVE: mulheres; prefeitas; democracia; partidos; Portugal.

This is an Open Access article distributed under the terms of the Creative Commons Attribution Non-Commercial License which permits unrestricted non-commercial use, distribution, and reproduction in any medium provided the original work is properly cited. 